\title{
PLACE AND PLACENESS
}

https://doi.org/10.4215/rm2020.e19008

\author{
Eduardo Marandola Jr a*
}

(a) Dr. in Geography. Professor at the Faculty of Applied Sciences at the University of Campinas, São Paulo (SP), Brazil.

ORCID: https://orcid.org/0000-0001-7791-9240. LATTES: http://lattes.cnpq.br/3962303942126121.

\author{
Article history: \\ Received 04 March, 2020 \\ Accepted 09 March, 2020 \\ Publisher 15 April, 2020
}

\section{(*) CORRESPONDING AUTHOR}

Address: UNICAMP. Rua Pedro Zaccaria,1300. CEP 13484-350. Limeira, (SP), Brasil.

E-mail: Eduardo.marandola@fca.unicamp.br

\begin{abstract}
Despite the efforts of different approaches to remove the place from its mere sense of formal geometric location, this idea continues to appear in geographic conceptions of place. In other words, the strength of theoretical recognition is often lost in conducting investigations of specific places and geographical situations, which are structured on the basis of the modern conception of subject (self-conscious) and object. The paper resumes the debate of the subject in modern philosophy from the ontological differentiation and the Kerhe in the Heideggerian perspective, in order to prompt the radicality of a topology as a geography of emergencies, starting from place as a way of being, that is, placeness.
\end{abstract}

Keywords: Subject; Res Extensa and Res Cogitans; Ways of Being; Topology.

\section{Resumo / Resumen}

\section{LUGAR E LUGARIDADE}

Apesar dos esforços de diferentes perspectivas em retirar o lugar de seu mero sentido de localização geométrica formal, este continua aparecendo nas formulações geográficas de lugar. Em outras palavras, a força do reconhecimento teórico, não raro, se perde na condução de investigações de lugares e situações geográficas específicas, as quais estruturam-se a partir de uma concepção moderna de sujeito (autoconsciente) e objeto. O artigo retoma o debate do sujeito na filosofia moderna, a partir da diferenciação ontológica e da Kerhe do pensamento heideggeriano, a propósito de incitar a radicalidade de uma topologia como geografia das emergências, a partir do lugar como modo de ser, ou seja, lugaridade.

Palavras-chave: Sujeito; Res Extensa e Res Cogitans; Modos de Ser; Topologia.

\section{LUGAR Y LUGARIDAD}

A pesar de los esfuerzos de diferentes perspectivas en retirar el lugar de su mero sentido de ubicación geométrica formal, este continúa apareciendo en las formulaciones geográficas de lugar. En otras palabras, la fuerza del reconocimiento teórico a menudo se pierde al realizar investigaciones de lugares y situaciones geográficas específicas, las cuales se estructuran a partir de una concepción moderna del sujeto (autoconsciente) y el objeto. El artículo retoma el debate del sujeto en la filosofía moderna, a partir de la diferenciación ontológica y de Kerhe del pensamiento heideggeriano, con el propósito de incitar la radicalidad de una topología como geografía de las emergencias, a partir del lugar como modo de ser, es decir, lugaridad.

Palabras-clave: Sujeto; Res Extensa y Res Cogitans; Modos de Ser; Topología. 


\section{INTRODUCTION}

Two of the most intriguing and obscure parts of M. Heidegger's famous text Building, Dwelling, Thinking are:

1)The reference to the bridge as a place and a provider of spaces: "The bridge does not first come to a location to stand in it; rather, a location comes into existence only by virtue of the bridge" (HEIDEGGER, 1971, p.152); and

2)the reference to the man-space relationship: "It is not that there are men, and over and above them space." (HEIDEGGER, 1971, p.155 - emphasis original).

I have already cited these excerpts myself, both in my $\mathrm{PhD}$ dissertation, which I defended over 10 years ago (MARANDOLA JR., 2008a). I explored the discussion on the bridge to think of circumstantiality as a sense of place (related to the Umwelt) (MARANDOLA JR., 2012). Moreover, many other references to these passages are available in different discussions, with emphasis on authors who have defended the topological turn in the Heideggerian thought such as Jeff Malpas $(2008 ; 2017)$ and Ligia Saramago $(2008 ; 2012)$.

However, despite thoroughly explored and discussed, in addition to being part of and influencing the geographical conceptions of place, there seems to be some difficulty for the radical implications of what is defended in greatly reverberating and impacting the way we conceive place. More than the understanding itself, there seems to be something that makes the reverberation more discursive than effective, thus causing an uncomfortable insistence effect on conceptions of space and place imbued in mere geometric principles that refer to the absolute space and to externality.

This called my attention once again during the course I taught on phenomenological discussions of place, in July 2019 , which motivated me to resume the theme in this article, in two movements: to investigate, as propaedeutics, the difficulty, and to reinforce, in a propositional sense, the radicality of possible implications of the sense triggered by those sentences.

As for the first movement, the central idea is that no matter how much we promote renovations and changes in perspective, whether based on Phenomenology, Hermeneutics, Existentialism, or other currents of thought that help us criticizing modernity, it seems to be a blind spot that maintains our understanding of space and spatiality (and, consequently, of geography and place) linked to the res extensa. This is implies a given understanding of the subject, nature, and the very subject-object relationship that privileges the subject as having the prerogative of knowledge.

Seeking to go beyond res extensa as a criticism of an egocentric and subjectivist conception of knowledge is not a movement exclusive to phenomenology. Throughout the 20th century, criticisms of modernity assisted in opening up a large gap in the Western thought, which put an end to the clear modern separation between res cogitans and res extensa. Authors influenced by Heterodox Marxist thought, such as H. Lefebvre or M. Santos, seek this in their understanding of social space and geographical space, respectively; also D. Massey, with his post-structuralist Neo-Marxism, reinforcing the event of place; G. Deleuze and F. Guatarri, with their becoming geophilosophy, are also examples of this movement. However, even geographical perspectives developed based on such orientations seem to have difficulties in rejecting such conceptions when it comes to starting from reflection and going to the investigation of specific geographical situations.

Thus, as a contribution for us to think about place from the radicalism expressed in Heidegger's initial citations, I will resume implications of the modern ontological differentiation between res cogitans and res extensa, especially from Descartes and Kant's perspective, seeking to retain the foundations of a given understanding of the knowledge centered on the subject, promoted by modern thinkers, and their implications for Geography. This debate, which might be the "blind spot," shall help us looking at the perspectives of place again, according to philosophy and geography, from a different perspective. I hope this can open up the possibility of a more-than-extensive geography, based on another understanding of the subject-object relationship, which is not oriented towards content, but towards a topology of emerging, of ways of being instead of substances: a geography of placeness rather than places. 


\section{DELVING INTO THE SUBJECT ISSUE}

An auditorium with air conditioning and old, bad windows. A table as a "pulpit" and a chair in front of an audience. What could be more hermetic than this? But, there is a camera that opens this sealed enclosure, creating a line of flight: an exit, but with one way only, because we can be heard, though we cannot hear. Hermeticism is thus maintained by the control exercised over the dynamics of the auditorium, its meaning, objective, duration, arrangement. It does not mean there is no interaction, such as our exchanges of looks and the gestures we make as someone positioned in the "pulpit" speaks and the others listen - after all, speaking and listening are bodily actions. In addition, there are smiles, whispers and, of course, questions, reflections, comments (written on paper, on the cell phone, or spoken up). There is a form in this hermeticism, within this impermeability that, without valuing it, I only describe it as an organized materiality that, at the same time, organizes itself. An affective tone, a very corporeality, an intentionality. A co-existence, a habit, a cultural practice, a custom. In other words: everything we know from our experiences as the "academic lecture" place. Or should I refer to it as the place for the academic lecture?

The need or not to use this preposition well expresses the nature of the issue before us. Not for grammatical purposes, but for reflecting on the meaning of place. The use or not of the preposition indicates the acceptance of the academic lecture as a place; or, conversely, it perceives the need of the academic lecture (as an event) for "a place" for it happen. In this case, an auditorium.

If, in this situation, someone asks you where you are, via WhatsApp, how would you respond? Would it be in the specific auditorium, with its number, name, and location (neighborhood, city, state), or would you indicate the name of the lecture you are attending?

The possible answers lead to differences in the understanding of the role of spatiality in experience and, more specifically, in the understanding of human beings and their existence. For us to reflect upon it, I propose to consider these differences based on the articulations, as established in modern philosophy, of res cogitans (the interiority, the intensive, inner thing) and res extensa (the externality, the extensive, outer thing), which allowed the structuring of all modern thought, including Geography, consecrated as the science of the extensive space.

Before concentrating on Geography itself, it is worth resuming the philosophical history that Edward Casey created about place in his fundamental work The fate of place (CASEY, 1998). When seeking the place, he observes the ways in which the concept is depicted in Western thought, resuming the Greeks (especially Plato and Aristotle), going through the ancient and medieval, the modern and the contemporary thinkers. One of the lessons I would like to emphasize from his valuable study is the movement that starts from the place (the Platonic khôra and the Aristotelian topos), goes through space, highlighting its supremacy among modern thinkers, and reaches the reemerging of the place in the criticism of modernity.

If, among the Greeks, there is a sense of intensiveness (Plato) and situatedness (Aristotle), which lead to the centrality of the place in relation to space, medieval and especially modern thinkers will promote such a major change in space that place practically disappears as a relevant category for thinking about human experience or existence.

Casey (1998) shows how the "where" is situated at the center of the Aristotelian concern in his Physics, in the Greek's search for determining the nature of things. However, this "where" issue is directly correlated with movement, which involves the ownership of bodies, the relationship between form and matter (and the surface) as well as the dynamics of change.

Bergson (2013), in his thesis on the concept of place in Aristotle, wonders why were the Greeks concerned with place instead of space? The answer, found in Physics, is the relationship between form and matter, which confer it the quality of content. Space is understood based on its use and filling (negation of the empty space), which refers to the understanding of the body as the juxtaposition of the parts (as an extension). This is result in "the place is born from the juxtaposition of the bodies," denominating space as "that which happens and changes the juxtaposition of bodies, that is, the condition of extension and movement." (BERGSON, 2013, p.155, free translation). According to Bergson, Aristotle changes his focus from space to place precisely in order to qualify space beyond its volume (indeterminate space), seeking what is contained and determined. "The Aristotelian place does 
not exist before the bodies, but it is born from the order and disposition of bodies." (BERGSON, 2013, p.161, free translation).

Extension, in this case, was separated from the body by the distinction between actuality and potentiality, separating the effective power of the members. With this operation, according to Bergson (2013), Aristotle no longer focused on the surface of the bodies, but rather emphasized the body as a whole, in order to deviate from extension. Modern philosophers (such as Leibniz) have joined place and extension and, therefore, they focused on space.

But the cornerstone of this movement was Descartes. If modern thinkers connected place and extension, this is due to the Cartesian self who made self-consciousness the reference for all knowledge (DESCARTES, 2004). The exercise of reason, by Cogito, is the only access to true knowledge. Even focusing on the world, for Descartes, consisted in a means to understand yourself and, at the same time, understanding the world equaled to understanding yourself (KUJAWSKI, 1969). How does this affect the understanding of place and its articulation?

In one of the lectures prior to Being and time (HEIDEGGER, 2012a), called The basic problems of phenomenology, Heidegger (2012b) examines some ideas about the being, within the context and purpose of its fundamental ontology. In chapter 3, he scrutinizes the hypothesis of modern ontology, from Descartes to Kant. Starting from the ontological difference between res extensa and res cogitans, created and supported by these authors, Heidegger shows how modern philosophy, by subjectifying knowledge through the conscious return to the self-subject without disregarding the traditional ontology. It is at the mercy of a mediocre being who does not wonder and neither delve into the multiplicity of ways of being, making an appropriate ontological questioning impossible.

For Heidegger, both Descartes and Kant are attached to existence in its sense of "presence in sight" as a basis for understanding reality. Although recognizing Kant's efforts and advances in seeking forms of subjectivation, for Heidegger, both philosophers carry an irremissible mark, which is the separation between the subject and the object: the self-conscious subject (whose fallibility and unsustainability Heidegger impeccably shows, as well as in famous passages of Being and time) and the object as that (res) which exists in relation to apprehension, the nature in its extensiveness.

What interests us in Heidegger's criticism is the repercussion of the modern ontological separation: on the one hand, the human being, on the other, nature; on the one hand, a self-conscious subject, on the other, the world that, from the subject's perspective, becomes an object/objectified; on the one hand, an entity that is whole by itself (self-conscious man); on the other, the "present in sight" nature. Basically, Heidegger (2012b, p.224) points to a limitation in the conceptualization of the subject as part of the self-evidence field, which deviates, from his perspective, from the possibility of modern thinkers to achieve "the very subject's way of being," that is, their intentional character as being-in-the-world as the very way of the being-there establishing relationships with what this subject is or not.

This criticism and the Heideggerian orientation towards the ontological differentiation between being and entity, as well as the very existence of human beings (being-there) and his formulation of the being-in-the-world, is a search for reformulating the possibility of the question about the being, going against tradition (as a component of his phenomenological method). Heidegger's (2012b) defends that the modern ontological hypothesis does not substantially rethink about the tradition, but only provides ontology with a disconcerting emphasis on the subject, constituting a subjectivation that, in Heidegger's criticism, is unsustainable.

Resuming the self, in the form of a self-conscious subject, linked to res cogitans, relegates all knowledge to the apprehension of res extensa, which assumes the form of nature. According to Descartes, space is directly associated with the extensiveness thing, but it has more attributes, as Casey (1998) pinpoints: space is absolute for Newton; it is relative for Locke and Leibniz; it is a point according to Positivist and Neopositivist conceptions.

All these conceptions of space are conceived based on the ontological separation between res cogitans and res extensa, which explains the emphasis on space among modern thinkers, making it easy to perceive the birth of Modern Geography in this same context. If we refer to Kant himself, who did not only reify, but made the Cartesian ontological separation even more conspicuous, it is easy to perceive his Geography (KANT, 1999) in the sense of a science of space, that is, of the res extensa: of 
extensiveness, of externality, of what is "present in sight," ontologically detached from the human being's own existence. The Geography linked to res extensa is an object for apprehension: it is a space of arrangement and organization that is always connected to a self-conscious subject whose prerogative is to know.

Within this context, if we resume the issue of naming the "academic lecture" place, we would be led to demand the presence of the preposition: place for the academic lecture, an auditorium. We would consider an understanding of space as absolute and geometric, normative by itself, which can be mapped, by definition, in the geographies like the geographer of The little prince does (SAINT-EXUPÉRY, 1999).

Such place as an extensiveness space, however, is not only absolute, but it can also be understood as relative. That is, the auditorium, built for certain purposes, may be more than one place depending on temporality and point of view. It is like a board of examiners' room, about which some people have pleasant memories, and others do not. Perhaps someone has met the love of their life in the same auditorium, or a precious friend for life. A lecture may have been paramount in the decision to pursue graduate studies, or to completely change your research. Or, yet, maybe it has been the place where someone decided to commit suicide. So many possibilities were raised in the same auditorium.

Nevertheless, it is worth noting that the relative space does not overcome the ontological separation between res cogitans and res extensa: it only disregards its absolute character, keeping the subject-object separation intact, in the aforementioned terms here discussed.

The understanding of a relative space greatly enriched the humanist perspectives in Geography, which attributed centrality to experience and existence, thus assuming the prerogative of the subject in the constitution of places. Cultural perspectives were also guided by such understandings, taking the question to the scope of social groups, understanding the meanings and representations collectively constituted as founders of places.

However, how much does a perspective of absolute space, which exists per se, is implicit in many of these perspectives, considering the meaning of place as a layer constituted from and on a material place that uses the preposition? On the other hand, by not suspending the separation, would the perspective of subject of these geographies be equally oriented towards a perspective of self-consciousness that ends up taking populations, cultures, and senses to the extensive field? Or, to use Heideggerian terms, how much of these perspectives, even if phenomenologically oriented, would have deemed existence as a "present in sight," self-evident, guided by a general mediocre being? To what extent have they broken the ontological separation, seeking the being-in-the-world, to use the Heideggerian expression, or the carnality, according to Merleau-Ponty (2007), or even the alterity, according to Lévinas (2011)?

Perhaps this persistence of a reference to the absolute or relative extensive space is what some contemporary perspectives, post-1990, denominate "essentialism." Even if I disagree with their use of the term, such seeks to name a confinement to a place spatiality that imprisons due to its fixity, its Hermeticism, and its (in)temporality. For example, we known the criticism of Doreen Massey and feminist geography to this perspective of place (whose primary target would be Yi-Fu Tuan), which led to the elaboration of a "global sense of place" (MASSEY, 1994) and, in the first decade of 2000, to an understanding of place as a "collection of histories until then" linked to event (MASSEY, 2008). Massey and other authors who followed this criticism were precisely seeking to provide motion and dynamism to a place that, according to them, was tied to Hermeticism and the crystallization of senses and identity itself.

Interestingly, in this perspective, temporality gains prominence to dynamize the place according to the understanding of event. This becomes a cornerstone, a glimmer of relationships in which space is dynamically involved, but which denies any connection with absolute space or even with the relative space of points of view. It is not relative, it is becoming: constant construction and deconstruction by contradictions and political struggles and desires. Even within the context of spatial imagination (speeches and representations - articulations between bio-, micro-, and macropolitics).

Indeed, there is an emerging of perspectives that seek this irruption, this suspension and criticism of the modern subject. Some seek to dilute the subject (Nietzsche, Heidegger, Deleuze-Guatarri), others seek to problematize and displace them, to rehabilitate them (Ricoeur, Foucault, Lévinas). How has 
Geography positioned itself in these debates?

For one, still in an incomplete or imprecise manner.

Malpas (2017), for example, accuses geographers of not properly dealing with the issue of place. Perhaps he is right. What is the matter? When the predominance of space has overwhelmed us, coming from Neopositivism perspectives, we sought two paths: the construction of space as a social instance, via Marxism and Neo-Marxism ideals, and an emphasis on place and space as experience and existence, via phenomenology and Existentialism. However, in both paths, we lacked radicalization to continually break our modern legacies, which consist in a double bad solution for the heart of the criticism against modernity: the basic epistemological problem of the subject-object relationship of an ontological nature, as we have observed with Heidegger. In other words, we have not been able to effectively position ourselves in order to redevelop our understanding of the subject and the object, maintaining, as a rule, structures enshrined in modernity and that, regardless of our efforts, once again confine us in the same explanatory cognitive structures of res cogitans, on the one hand, and res extensa, on the other.

In other words, we reproduce the senses and feelings of an egoic subject who does not suffer any distress, oriented to the must-be and to the must-have-been, on the one hand, and to a space and a place that consist in the complete externality as extensiveness, as absolute space, as geometric spatiality and that opposes any perception or subjectivity (even if connected by affectional bonds or feelings of belonging), on the other hand. We also reproduce that perspective of the mediocre being, who, precisely for not wondering about the ways of being, reproduces an Eurocentric, masculine, and middle-class view: the neutral point of a traditional ontology.

Even with the perspective of experience and existence, as incorporated by the Humanist Movement, the reference - which is emphasized - is the subject's apprehension of the senses. What is poorly considered, however, is the consequence of this emphasis on the subject: the objectification of the geographical subject relegated to the complete externality of res extensa.

And this is even more sensitive in our research, since we proposed to investigate geographical situations and realities: places, regions, landscapes, territories... How much of our research ends up, like Descartes, bringing us to ourselves and not to the "world," "being-in-the-world," as the one who is beyond the subject-object ontological separation?

Cresswell (2015) reinforces this criticism by opposing the perspective of place associated with being-in-the-world (from Phenomenology and Existentialism) from the perspective he calls "social construction." In fact, in a systematization effort, he ends up identifying three approaches: (1) descriptive, linked to the unique and particular characteristics of the place, of ideographic nature, carried out by regional geographers; (2) social construction of the place, which deems the particularities of places as social processes, associated with Marxists, feminists, and post-structuralists; and (3) the phenomenological approach, which comprises the existence founded on the place, carried out by humanist, neohumanist geographers, and phenomenological philosophers.

These approaches, although superimposed in many cases, do not disregard the pitfalls that lie ahead: all can reproduce pure extensiveness, of time and space, taking spatiality as preestablished: empty space where substance (subjects and materiality) present itself - a "present in sight" reality.

We can easily think about that: we, geographers, like other people, continue not to give up on that preposition ("place for the academic lecture"), that is, to indicate the clear separation between a place and the events that may occur in it, or that between people and places. For us, it is very difficult to clearly state that the "academic lecture" place goes beyond the separation between res cogitans and res extensa. It seems self-evident to differentiate what each of us can perceive about the "present in sight" reality available to our senses. It seems self-evident that talking about objects per se and showing they have an existence regardless of morals, senses, reason, and the will of any action that every subject would be very reasonable and acceptable. The same occurs when stating that every subject, every self-thinker in an academic lecture, is a subject because of their self-awareness, and that they are simply in place, but they are not the place itself. These sentences seem commonplace, self-evident, true, right?

It is precisely against this self-evidence, this truth linked to self-consciousness, and the ontological separation between res cogitans and res extensa that we must act, in search of a more-than-extensive geography. To do so, I defend an adverbial need that potentiates the multiplicity of ways of being, desubstantializing the place and welcoming it as an emergency and an irruption. 


\section{PLACE AS THE TOPOLOGY OF BEING}

We can now resume the two sentences of Building, Dwelling, Thinking, looking at them from the perspective of the ontological separation. These sentences express a change in Heidegger's own thought about space, which was also at the mercy of the traditional conception until Being and time, presenting itself in another way from the Kehre of his thought, commonly called "the turn" (MALPAS, 2008; SARAMAGO, 2012).

This turn is less oriented towards what Heidegger points out, and more towards what we can glimpse from the consequences of the statement, in the abysmal sense: "The bridge does not first come to a location to stand in it; rather, a location comes into existence only by
virtue of the bridge."

(HEIDEGGER, 1971, p.152)

We can understand, even without resorting to the set of Heidegger's explanations about the bridge and the quadrature, the anti-modern radicality of the collocation: it is not the space, as res extensa, that has extensive as a "present in sight" reality that allows the existence of places. The bridge does not stand anywhere. A place comes into existence because of the bridge.

Space, therefore, was not there to be filled, like a void with no function, or a preexisting objectified geometry. "The location is not already there before the bridge is" (HEIDEGGER, 1971, p.151), but it emerges because of the act of building, which does not require an extensive construction to happen, although it may also be the case. Heidegger does not eliminate extensiveness, but starts focusing on its Raum sense rather than on the extensive content of space (as we could still observe in Being and time), that is, to make room as arrangement, tidying actions which, together with the Latin sense of spatium (arrangement in positions, based on topological relations of proximity and distance), refers to the in-between space, and not to extensive as an abstract geometric or algebraic positioning.

We must not underestimate the strength of this movement. The inclusion of the sense of the topological making room allows Heidegger (1971, p.152 - emphasis original) to state: "Accordingly, spaces receive their being from locations and not from "space." "From space" is the extensive space, which refers to the modern space, while spaces always have a relative meaning due to the positionality, situatedness, and emerging of places, from things themselves.

Heidegger, in a single movement, no longer focuses on the issue of the subject-object relationship, which eliminates from space and place the possibility of being considered as objects and mere extensiveness: the effective self-evident reality. He considers that extensiveness is a fact, and yet, it is not what constitutes the essence of space and place.

The suggestions for this movement were foreseen prior to modernity. According to the Aristotelian formulation, as we observed, topology is at the base of the proposition of place not as preexisting, but rather as co-emerging from the disposition of bodies. The difference lies in the radicalization of the proposition from the replacement of the ontological difference, with existence itself being constituted based on this topology (MALPAS, 2008).

But if place and space are topological, constituted by this relational positionality of emergencies beyond extensiveness, what is the role of the res cogitans subject in this arrangement?

The second provocative sentence paves the way for this reflection:

"It is not that there are men, and over and above them space."

(HEIDEGGER, 1971, p.155 - emphasis original)

Reverberating this suggestion seems even more challenging for our geographical surveys. Nevertheless, it is based on the bond established by intentionality, which allows taking the first step towards the res cogitans and res extensa ontological separation, consisting of the immediacy and the very way of the being-there: inhabiting. 
The sentence evokes us to radicalize the understanding of the essential meaning of space linked to existence, not as a determination, but rather as a co-emerging. Therefore, place is always considered within the context of a being-in-the-world, which implies that it does not preexist and neither is fixed: thus being an emergency in this topological relational set. On the other hand, this implies that thinking about phenomena related to human beings regards a spatiality not in the sense of its location, but of its dynamic and eruptive positionality, which is constituted by and in the places. Not as receptacles, but as extensiveness. Hence, would space and place be in the field of interiority, as a perspective of feelings, affections, desires, and bonds?

Here, once again, the spectrum of the modern ontological separation manifests itself, making us oscillate between subject and object, focusing on the subjectification of knowledge. Resorting to interiority would make us reinforce the subject and characterize space and place as external objects again. "It [space] is neither an external object nor an inner experience" (HEIDEGGER, 1971, p.154) is the sentence that precedes the statement in question.

These understandings are not only found in Heidegger, but in other perspectives that criticize the ontological separation of modernity and seek to emphasize the emergencies, the becoming, the motion, the event, and the situatedness, that is, the intensiveness. As I have previously mentioned, I am certain of the spread of the understanding of such issues. However, the acceptance of such positions does not seem enough for us to name the "academic lecture" as a place without considering that, in the end, it refers to the separation between interiority and externality as subject and object. Now, let us focus on another point: how to deem this place as an emergency, beyond the subject-object separation, or to assign the emphasis on interiority or externality?

I would like to suggest for us to think about the problem of the denomination itself: place and space, approaching the issue from the perspective of a linguistic problem. Since we make a move due to the criticism to modernity, still with and by its categories, which involves different facets of our experiences, perhaps we need some adjustments in language to displace the ontological sense of place from the absolute, specific, or relative separation of space as extensiveness.

Thus, I would like to suggest for us to inflect place into placeness, which perhaps helps us thinking more deeply and beyond the modern ontological separation.

I could deepen topology as a way of disclosing the ways of being, general and determined ones, as Jeff Malpas $(2008,2017)$ has systematically done, but allow me to follow another path, properly geographic. I would like to resume ideas from authors of the Humanist Movement who are often in the spotlight, accused of promoting Essentialism and of not overcoming the subject-object separation in their perspectives.

My objective in doing so is to reinforce the nonlinear or non-historicist sense of Casey's (1998) philosophical history about place. Actually, this sense expresses a movement that is related to the spirit of the time and the pressing issues that fuel great philosophical movements. Nevertheless, the coexistence and persistence of movements to reinforce the ontological separation and the search for its redevelopment/confrontation coexist and, in the case of science, reverberate in a nonlinear way. With this revisitation to Humanist geographers, I also seek to show that sometimes the difficulty in overcoming the modern ontological separation is in the way we see it, which leads us to read the authors based on this sense from the beginning. That is why another language seems necessary to help us express, think, and be in different ways.

\section{PLACENESS, RATHER ADVERBIAL NEED \\ THAN PLACE: THE}

I would like to resume the central concern of Humanist geographers, who were in search of an empirical and experiential perspective of space, which leads them to the place in the opposite direction and against the prevailing space in the Geography of the time. What motivated these geographers to seek the place is closely related to the confrontation with the supremacy of space and its rigid subject-object ontological separation. It is not by chance that Neo-Marxism perspectives, when also facing the need to go beyond the extensive space, resort to the place, as aforementioned. 
Without resuming the historicity of this geography, I would like to retain the way in which placeness is already present, though with little emphasis on the way we perceive the work of such geographers, in the constitution of the phenomenological understanding of place in Geography. The example of Edward Relph and Yi-Fu Tuan is enough for me to reinforce the argument.

There are important differences in the way E. Relph addresses the understanding of place in his early studies, especially in his work Place and Placelessness, and in studies that came to light from the following decade onwards, in which we observe a deepening of the consequences of an ontological perspective for his research. Conversely, in his classic work, Relph (1976) points not only to places as locations or sites, even in the affective sense and related to meanings, but he addresses the sense of placeness and the placelessness as key in the constitution of the place. This adverbialization attributes the constitution of place an existential dynamics related to other scales of constitution of spatialities. Despite the author makes a somehow schematic reading, seeking to characterize different forms of space and to enumerate the ways in which places, within relationship between interiority and externality, are constituted, the result is less of a catalog for reading places, as res extensa, and more of a mosaic of possibilities for the manifestation of placeness.

His typifications precisely aim at developing the adverbial meanings of ways of being, although in Place and Placelessness this does not appear with the accuracy or depth that it does so later. But there, one can no longer see place as res extensa, as an object, but as a place that, focused both on the sense of place and its constructed materiality, allows being inhabited in different ways.

A text written in 1985 was differently conceived, when the author specifically dedicated himself to an ontological discussion, relating scientific geography, geographical experience, and being-in-the-world. He compares the implications of the clash between the scientific and experiential fields via the Heideggerian being-in-the-world concept, seeking to evolve the considerations about the centrality of the experience of place to other geographical concepts, such as landscape, space, and region (with the significant absence of territory), as geographic modes of existence (RELPH, 1985). Although placeness is not explicitly addressed in this text, the sense of going beyond the general being, towards the geographically determined beings-in-the-world, allows us to project an understanding of place that transcends the dichotomy res cogitans and res extensa. In fact, in this text Relph is mainly guided by the existential analysis of Being and time, making use of the distinction between present-at-hand and ready-to-hand modes of being to differentiate the perspective of place from scientific geography, focused on this extensive instrumentality of "present in sight," whereas the perspective of place from the being-in-the-world would be oriented towards geographical experiences.

This geographical experience, however, in order to present itself as an effective overcoming of the modern ontological separation, needs to take place in-between space, neither in the interiority nor in the externality, and such categorizations are more problematic for language than ways to deal with the matter in question. In the case of Relph's text, the constant reference to place as a phenomenon does not sufficiently splits the self-evident language, which could be enhanced by insisting on the adverbialization of placeness, and which he later resumed in his works (RELPH, 2012). On the other hand, his ontological concern has an epistemological background, which means that the adoption of the Heideggerian terminology being-in-the-world is not enough to break the modern ontological separation, since, deep down, there is a concern oriented towards the subject who geographically experiences, exists, and knows. A very similar effect can be observed in my $\mathrm{PhD}$ dissertation or in my subsequent studies on dwelling at risk and the vulnerability of the place (MARANDOLA JR., 2008a; 2008b).

Tuan's case is even more emblematic, due to his wide influence and the repercussion of his work worldwide. Two of his first books remain the most cited, translated, and disseminated ones: Topophilia and Space and place, precisely because of the originality of their contribution in bringing the centrality of the place from the perspective of experience (TUAN, 2012; 2013).

His conception of place is as much criticized as it is celebrated, with several meanings and changes in its trajectory. His books are full of meanings of place and space, like a phenomenological investigation of ways of being. From my point of view, he is mostly concerned not with defining space and place, something he does so in an almost childlike way: rather, Tuan is more concerned with the phenomenon of experience, that is, how and what are the possibilities of place-related experiences, and space-related experiences, and what this implies in creating a good life. In other words, I could say that 
Tuan's work does not aims at supporting analyses of specific places, as we often do in research, since it is not a systematic treatise of possibilities of meanings of places. Rather, his work is oriented towards a universal sense of place, as an experience of the world, and to a certain extent quite oriented towards a self-subject who thinks and feels the world.

Thus, for one, the problem in Tuan's work is not his supposedly romantic or idealized view of the affective relationships of the place (something that, for me, is not corroborated as a criticism), but his adherence to a mediocre, self-conscious being who resists the splits and distresses that come from spatiality. Basically, Tuan is a modern thinker, and therein lies the full sense of his humanism that refers to self-consciousness. Nevertheless, his emphasis on experiences and meanings of place are worthy as adverbialization if we displace it from the subject to the in-between space, as geographical modes of existence, beyond internality or externality. What would happen if we read Tuan exchanging places for placeness?

\section{THE RESILIENCE OF EXTENSIVENESS}

This brief review of the works of Relph and Tuan assists us in glimpsing, perhaps, one of the problematic issues before us: recognizing the presence and manifestation of effects caused by the modern ontological separation that reverberate in our thinking (including our reading of the other authors) and, at the same time, recognizing and radicalizing efforts that allow us to split the language and go beyond the fixation of the sense of place based on its denomination.

Attributing place with motion per se is not a solution; after all, movement is also tied, according to the metaphysical tradition, to an extensive base in which positionality occurs in an empty space. The emphasis on placeness, on the contrary, directs us to a specific ontological scope of the manifestation of emergencies, in which the question about the use or not of the preposition is actually ineffective. The place phenomenon, considered based on the placeness of a more-than-extensive geography, is not constituted from subjects and objects, but from emergencies, which essentially intertwine spaces, places, and entities in action, in a relational topology that, in its eventual presentification, is not developed from a historical background, but from an event.

Placeness, thus understood, could help us thinking about the academic lecture in its multiple manifestation, which emphasizes the effort in the field of language not to objectify or turn beings-in-the-world into entities, treating them either as subjects or as objects.

As exposed in the title of this article, this does not imply a denial of extensiveness, but of a given understanding of its articulation with the objectifying externality. Conceiving space beyond this abstract dimension, bringing it to the scope of topology, seems to provide possibilities for thinking about the place in its adverbalization.

Does this tackle the modern ontological separation and its effects on the subjectification or objectification of knowledge and geography? Certainly not, but it does pave the way for us to face this question, which is still poorly developed in geography and that, as I pointed out, directly affects our work, which, for being very connected to an extensive social space, easily leads us to the reproduction of the separation between subject and object - which, in its turn, even in perspectives oriented towards interiority, as aforementioned, ends up circumscribing space and place according the objectively outer extensiveness.

It is an invitation to radicalization, to an abysmal immersion. Even Descartes, one of those responsible for the emphasis on the subject in modernity, can be understood as a thinker concerned with the world. But a world that, first, goes through the consciousness of an ego that is self-referential. Thus, the contemporary need to split this ego in opening to the Other and to what is different is paramount so that place is not the temple of the mediocre beings, who positions themselves as universal and a measure of the must-be. Placeness, as a topological emergency, can help us thinking in a situated way about these geographicities that do not occur in space, but rather constitute themselves as spaces-between from relations of placeness existentially signified in their multiplicity, coexistence, and conflict.

This seems to be one of the major challenges for geographies of place, since we are continually resuming the extensive space or other facets of its modern understanding. It seems that we mix extensive space with geography, in a linear way. Sometimes, however, in order to escape from this, we make use 
of subjectivation, focusing on the self and on the disincarnated language.

We could think that place is a way of being, expressed by placeness. This does not imply bringing it to the being or to the self, since being is manifested in entities, in the worldliness of being-in-the-world. Ways of being may consist in irruption, life, pulsation, motion, encounter, reunion, co-belonging, tension, exceedance, clash.

Werther Holzer, in a recent study, helps us thinking of this clash. In a text in which he reflects on the relationship between territory and place, he uses placeness as an expression of the dialogical relations established in the movement of territoriality and place:

Geographicity, which expresses the materiality of the geographical space, is shared in our daily experiences with placeness, which, in turn, expresses exactly this dialogical relationship of beings in motion with places and paths that, as a pause, as an intimate coexistence, arrange and delimit the spaces. (HOLZER, 2013, p. 24, free translation)

Within this context, placeness refers to the sense of sharing and transit between the intensive and the extensive thing, which seems key for the place to also be understood from the alterity perspective (LIMA, 2019).

The openness to alterity and ways of being does not imply being outside the extensive volumetric space, but one is not in it as pure objectivity. That is why changing the language for placeness can assist in thinking of and expressing, in terms of geographic modes of existence, which of them topologically constitute the ways of being-in-the-world, including the multiplicity of entities, beyond the human being.

Would this be a disincentive to talk about specific places, those that appear as "present in sight" in the extensiveness? Not at all, because they are there. But it is important to understand the ways of being that are articulated and tensioned, in order to allow a geography beyond the extensiveness, but also related to it.

This perspective, as a draft that requires work and reflection, is one among several that is oriented towards the in-between spaces (betweenness), the boundaries and developments of language, a topology of the being and for contemporary confrontations about identity, difference, and colonialism, which place the radical perspective of the Other as key to all these confrontations.

But, to this end, I believe we need to resume the reflection on the limits and possibilities of the subject (and their relationship with place) and its implications for a thought that geographically emerges.

\section{REFERENCES}

BERGSON, Henri. O que Aristóteles pensou sobre o lugar. Campinas: Ed. Unicamp, 2013.

CASEY, Edward. The fate of place: a philosophical history. Berkley: University of California Press, 1998.

CRESSWELL, Tim. Place: an introduction. 2ed. London: Wiley Blackwell, 2015.

DESCARTES, Rene. Meditações sobre Filosofia Primeira. Trad. Fausto Castilho. Campinas: Ed. Unicamp, 2004.

HEIDEGGER, Martin. Construir, habitar, pensar. In: HEIDEGGER, Matin. Ensaios e conferências. Petrópolis: Vozes, 2001.

HEIDEGGER, Martin. Os problemas fundamentais da fenomenologia. Petrópolis: Vozes, 2005.

HEIDEGGER, Martin. El arte y el espacio. Trad. Jesús Adrián Escudero. Barcelona: Herder, 2010.

HEIDEGGER, Martin. Ser e tempo. (Trad. Fausto Castilho) Campinas: Ed. Unicamp, 2012.

HOLZER, Werther. Sobre territórios e lugaridades. Cidades, v.10, n.17, p.18-29, 2013. 
KANT, Immanuel. Géographie. Trad. M. Cohen-Halimi; M. Marcuzzi; V. Seroussi. Paris: Aubier, 1999.

KUJAWSKI, Gilberto de M. Descartes existencial. São Paulo: Herder, 1969.

LÉVINAS, Emmanuel. De outro modo que ser ou para lá da essência. Tradução de José L. Pérez; Lavínia L. Pereira. Lisboa: Centro de Filosofia da Universidade de Lisboa, 2011.

LIMA, Jamille S. Identidade e lugar na metafenomenologia da alteridade Payayá. GeoTExtos, v.15, n.2, p.13-33, 2019.

MALPAS, Jeff. Heidegger's topology: explorations in the topology of being. Cambridge: MIT Press, 2008.

MALPAS, Jeff. Heidegger and the thinking of place: explorations in the topology of being. Cambridge: MIT Press, 2017.

MARANDOLA JR., Eduardo. Habitar em risco: mobilidade e vulnerabilidade na experiência metropolitana contemporânea. 2008a. Tese (Doutorado em Geografia) - Instituto de Geociências, Universidade Estadual de Campinas.

MARANDOLA JR., Eduardo. Entre muros e rodovias: os riscos do espaço e do lugar. Antropolítica, n.24, n.1,2, p.195-218, $1^{\circ}$ Sem. 2008b.

MARANDOLA JR., Eduardo. Lugar enquanto circunstancialidade. In: MARANDOLA JR., Eduardo; HOLZER, Werther; OLIVEIRA, Lívia (Orgs.) Qual o espaço do lugar? Geografia, Epistemologia, Fenomenologia. São Paulo: Perspectiva, 2012. p.227-247.

MASSEY, Doreen. Space, place and gender. Minneapolis: University of Minnesota Press, 1994.

MASSEY, Doreen. Pelo espaço. Rio de Janeiro: Bertrand Brasil, 2008.

MERLEAU-PONTY, Maurice. O visível e o invisível. São Paulo: Perspectiva, 2007.

RELPH, Edward. Place and placelessness. London: Pilon, 1976 [2010].

RELPH, Edward. Geographical experiences and being-in-the-world: the phenomenological origins of geography. In: SEAMON, David; MUGERAUER, Robert (Eds.) Dwelling, place \& environment. New York: Columbia University Press, 1985. p.15-32.

RELPH, Edward. Reflexões sobre a emergência, aspectos e essência de lugar. In: MARANDOLA JR., Eduardo; HOLZER, Werther; OLIVEIRA, Lívia (Orgs.) Qual o espaço do lugar? Geografia, Epistemologia, Fenomenologia. São Paulo: Perspectiva, 2012. p.17-32.

SAINT-EXUPÉRY, Antoine. Le pettit prince. Paris: Folio, 1999.

SARAMAGO, Ligia T. A topologia do ser: lugar, espaço e linguagem no pensamento de Martin Heidegger. Rio de Janeiro: Loyola, 2008.

SARAMAGO, Lígia. Como ponta de lança: o pensamento do lugar em Heidegger. In: MARANDOLA JR., Eduardo; HOLZER, Werther; OLIVEIRA, Lívia (Orgs.) Qual o espaço do lugar? Geografia, Epistemologia, Fenomenologia. São Paulo: Perspectiva, 2012. p.193-225.

TUAN, Yi-Fu. Topofilia: um estudo da percepção, atitudes e valores do meio ambiente. (Trad. Lívia de Oliveira) Londrina: Eduel, 2012.

TUAN, Yi-Fu. Espaço e lugar: a perspectiva da experiência. (Trad. Lívia de Oliveira) São Paulo: Eduel, 2013. 